\title{
Zinc Intake, Zinc Serum Levels, and Intelligence in School Children in Rural Areas
}

Rostika Flora ${ }^{1 * \mathbb{D}}$, Nur Alam Fajar ${ }^{1} \mathbb{D}$, Fatmalina Febry ${ }^{\mathbb{D}}$, Indah Yuliana ${ }^{2}$, Yuliarti Yuliarti ${ }^{2}$,

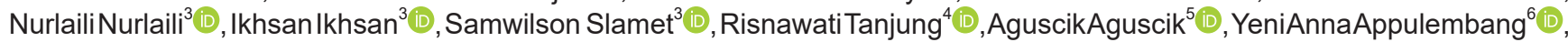
Mohammad Zulkarnain ${ }^{7}$

${ }^{1}$ Study Program of Public Health, Faculty of Public Health, Sriwijaya University, Indonesia; ${ }^{2}$ Study Program of Nutrition, Faculty of Public Health, Sriwijaya University, Indonesia; ${ }^{3}$ Study Program of D-III Nursery, Faculty of Mathematics and Science, Bengkulu University, Indonesia; ${ }^{4}$ Study Program of Environmental Health, Polytechnic of Health of the Ministry of Health, Medan, Indonesia; ${ }^{5}$ Study Program of Nursery, Polytechnic of Health of the Ministry of Health, Palembang, Indonesia; ${ }^{6}$ Study Program of psychology, Faculty of Medicine, Sriwijaya University, Indonesia; ${ }^{7}$ Public Health Science, Faculty of Medicine, Sriwijaya University, Indonesia

Edited by: Mirko Spirosk Citation: Flora R, Fajar NA, Febry F, Yuliana I, Yuliarti Y,
Nurlaili N, Ikhsan I, Slamet S, Tanjung R, Aguscik A, Appulembang YA, Zulkarnain M. Zinc Intake, Zinc Serum Levels, and Intelligence in School Children in Rural Areas. Open Access Maced J Med Sci. 2021 Apr 25; 9(E):394-397. https://doi.org/10.3889/oamms. 2021.586 Keywords. Zinc serum; Zinc intake; Level of intelligence; School children; Rural are *Correspondence: Rostika Fora, Study Program University, Indonesia E-mail: rostikaflor smail com Received: 09-Feb-2021 Revised: 26-Mar-202 Accepted: $15-\mathrm{Apr}-202$ Copyright: (c) 2021 Rostika Flora, Nur Alam Faja Fatmalina Febry, Indah Yuliana, Yuliarti Yuliarti Nurlaili Nurlaili, Ikhsan Ikhsan, Samwilson Slamet, Risnawati Tanjung, Aguscik Aguscik,
. Yeni Anna Appulembang, Mohammad Zulkarnain Funding: This study was supported by a research gran from the Indonesian Ministry of Research, Technology and Higher Education competing interest exists
Open Access: This is an open-access article distributed under the terms of the Creative Commons AttributionNonCommercial 4.0 International License (CC BY-NC 4.0)

\section{Abstract}

BACKGROUND: Children in rural areas are susceptible to zinc deficiency. Zinc deficiency in children can affect cognitive function in children. Zinc plays a role in cellular function and critical brain growth processes, including cel replication, DNA and RNA synthesis, and the release of neurotransmitters.

AIM: This study aimed to analyze the condition of zinc deficiency and its relationship with the level of intelligence in children in rural areas.

METHODS: The study design was cross-sectional, with a sample of 44 elementary school children aged 9-12 years taken randomly. Blood was drawn to measure serum Zn-levels, and serum Zn-levels were measured using Colorimetric Assay Kit (E-BC-K137). Zinc intake data were obtained from the food recall form, which was carried out 3 $\times 24 \mathrm{~h}$. The level of intelligence is measured by the Culture Fair Intelligence Test method. The sample characteristics data obtained through a questionnaire. Furthermore, the data were analyzed using the Chi-square test.

RESULTS: About $84.2 \%$ of children with insufficient zinc intake had low serum Zn-levels. There was a significant relationship between zinc intake and serum zinc levels $(p=0.026$; $P R=4.293)$. Children with low serum zinc levels of $96.5 \%$ have intelligence levels below average. There was a significant relationship between serum zinc levels and intelligence level as well $(p=0.001 ; P R=24,500)$

CONCLUSION: Zinc deficiency in children is characterized by low serum Zn-levels. Low serum Zn-level is caused by low zinc intake, thus children with low serum $Z n$-levels are at risk of having intelligence level below average. Therefore, health education about the importance of zinc intake in children should be given to parents, so that the incidence of zinc deficiency in children can be reduced.

\section{Introduction}

In Indonesia, micronutrient deficiency in children is relatively high. The $\mathrm{Zn}$ deficiency rate reaches $17 \%$ [1]. In 2006, the prevalence of zincdeficient children in Indonesia was $36.1 \%$ [2]. According to the $\mathrm{WHO}$, zinc deficiency is one of the causes of death in children in moderate developing countries [3]. While according to the International Zinc Nutrition Consultative Group, zinc deficiency can cause $40 \%$ of children to become stunted [4]. Indonesia has a low rate of zinc intake $>25 \%$ and a stunting rate $>20 \%$, so it can be concluded that Indonesia is still at risk of experiencing severe zinc deficiency [5].

Zinc (zinc) is a micronutrient with an essential function in brain development, especially in the nervous system's function (neurotransmitter). Zinc plays a role in increasing brain intelligence and learning ability in children [6]. Zinc is related to protein and functions as a brain cell structure and neurotransmitters involved in brain memory to affect cognitive development and learning achievement [7]. Zinc supplements can improve children's memory and concentration in learning and IQ [8].

Factors causing micronutrient deficiencies include poverty, low education levels, and low access to health-care centers [9]. Research in Iran states that zinc deficiency tends to be higher in rural areas than in urban areas. In children who have families with lowincome levels, zinc deficiency often occurs because most of the intake comes from plant foods and eating little animal foods [10]. Vegetable foods contain a lot of phytate which inhibits zinc absorption, while animal foods do not contain phytate so that zinc can be absorbed optimally [11]. This study aimed to analyze the condition of zinc deficiency and its relationship with the level of intelligence in children in rural areas.. 


\section{Method}

This research was a cross-sectional study which was conducted in Lubuk Rumbai Village, Tuah Negeri District, with a total sample of 44 children. The sample was carried out randomly on elementary school children aged 9-12 years. Measurement of serum zinc levels was carried out by taking blood through cubital veins and measured using the Zinc $(\mathrm{Zn})$ Colorimetric Assay Kit (E-BC-K137), while the zinc intake data were obtained from a food recall form that was carried out 3 $\times 24 \mathrm{~h}$ with non-consecutive days. The results of food intake recall were recorded, analyzed with Nutrisurvey software, averaged, and compared with the Nutritional Adequacy Rate (RDA). Zinc intake was included in the insufficient category if $<77 \%$ of the value of the Adequacy Rate of Nutrition (RDA) and in the sufficient category if $\geq 77 \%$ of the value of the Adequacy Rate of Nutrition (RDA). Measurement of the level of intelligence was carried out using the Culture Fair Intelligence Test method. Data on the characteristics of children were obtained through a questionnaire. Further data were analyzed using the Chi-square test. This research had received ethical approval from the Ethics Commission of the Faculty of Public Health, Sriwijaya State University No. 161/UN9.1.10/KKE/2020.

\section{Results}

Based on the characteristic data obtained from the questionnaire, it was found that $59 \%$ of the children were male, $22.7 \%$ of the children had a nutritional status of stunting. Data on child characteristics revealed that $63.6 \%$ of mothers and $65.9 \%$ of fathers have low education. Most of the mothers did not work (54.5\%) and $45.5 \%$ of fathers worked as farmers. Most of the parents $(77.3 \%)$ had a low economic status (Table 1$)$. The results of measuring zinc in children proved that $43.2 \%$ of children had insufficient zinc intake and $65.9 \%$ of children had low serum zinc levels (Table 2). As for measuring the level of intelligence, it was found that $81.8 \%$ of children had a level of intelligence below average (Table 3). This finding may also be associated with low level of parental education, not only zinc deficiency

The results of the Chi-square test in Table 4 shows that children with a low zinc intake of $84.2 \%$ had low serum zinc levels as well. There was a significant relationship ( $p=0.026$; $P R=4.923$ ) between zinc intake and serum zinc levels in children. Children with low zinc intake were 4923 times more likely to have low serum zinc levels. Table 5 shows that, for children who have low serum zinc levels, $96.5 \%$ have an intelligence level below the average. There was a significant relationship
( $p=0.001 ; P R=24.500)$ between serum zinc levels and intelligence levels in children. Children who have low serum zinc levels are at 24,500 greater risk of having intelligence levels below average.

Table 1: The frequency distribution of characteristics of elementary school children in Lubuk Rumbai Village

\begin{tabular}{lll}
\hline Frequency distribution & $\mathrm{n}$ & $\%$ \\
\hline 1. Gender & 26 & 59.0 \\
a. Male & 18 & 41.0 \\
b. Female & & \\
2. Nutritional status & 10 & 22.7 \\
a. Stunting & 34 & 77.3 \\
b. Normal & & \\
3. Mother's level of education & 28 & 63.6 \\
a. Low & 16 & 36.4 \\
b. High & & \\
4. Mother's job & 2 & 4.6 \\
a. Civil Servant & 12 & 27.3 \\
b. Farmer & 6 & 13.6 \\
c. Private-Employee & 24 & 54.5 \\
d. Unemployment & & \\
5. Father's level of education & 29 & 65.9 \\
a. Low & 15 & 34.1 \\
b. High & & \\
6. Father's job & 2 & 4.5 \\
a. Civil Servant & 20 & 45.5 \\
b. Farmer & 19 & 43.3 \\
c. Private-Employee & 3 & 6.7 \\
d. Unemployment & & \\
7. Economic status & 34 & 77.3 \\
a. Low & 10 & 22.7 \\
b. High & & \\
\hline & &
\end{tabular}

Table 1 shows that $59.0 \%$ of children are male and $22.7 \%$ of children are stunted, and $77.3 \%$ of children come from families with low economic status. As many as, $63.0 \%$ of mothers have low education, and $54.5 \%$ of mothers are not working. About $65.9 \%$ of fathers have low education, and $45.5 \%$ of fathers work as farmers.

Table 2: The frequency distribution of zinc measurement results in children

\begin{tabular}{lll}
\hline Frequency distribution & $\mathrm{n}$ & $\%$ \\
\hline 1. Zinc intake & & \\
a. Deficient & 19 & 43.2 \\
b. Sufficient & 25 & 56.8 \\
2. Zinc serum level & & \\
a. Low & 29 & 65.9 \\
b. Normal & 15 & 34.1 \\
\hline
\end{tabular}

Table 2 shows that $43.2 \%$ of children had insufficient zinc intake, and $65.9 \%$ of children had low serum zinc levels.

Table 3: The frequency distribution of measurement results for intelligence level in children

\begin{tabular}{lll}
\hline Frequency distribution & $\mathrm{n}$ & $\%$ \\
\hline Intelligence level $(\mathrm{IQ})$ & & \\
a. Below average & 36 & 81.8 \\
b. Average and above average & 8 & 18.2 \\
Total & 44 & 100 \\
\hline
\end{tabular}

Table 3 shows that $81.8 \%$ of children have a level of intelligence below average, and only $18.2 \%$ of children have an intermediate level of intelligence and above average.

Table 4: The relation between zinc intake and serum zinc levels in children

\begin{tabular}{|c|c|c|c|c|c|c|c|c|}
\hline \multirow[t]{3}{*}{ Zn Intake } & \multicolumn{4}{|c|}{ Serum Zn-Level } & \multirow{2}{*}{\multicolumn{2}{|c|}{ Total }} & \multirow[t]{3}{*}{$\mathrm{p}$} & \multirow{3}{*}{$\begin{array}{l}\mathrm{PR} \\
95 \% \mathrm{Cl}\end{array}$} \\
\hline & \multicolumn{2}{|c|}{ Low } & \multicolumn{2}{|c|}{ Normal } & & & & \\
\hline & $\mathrm{n}$ & $\%$ & $\mathrm{n}$ & $\%$ & $\bar{n}$ & $\%$ & & \\
\hline Deficient & 16 & 84.2 & 3 & 15.8 & 19 & 100 & 0.026 & 4.923 \\
\hline Sufficient & 13 & 52.0 & 12 & 48.0 & 25 & 100 & & $(1.142-21.232)$ \\
\hline Total & 29 & 65.9 & 15 & 34.1 & 44 & 100 & & \\
\hline
\end{tabular}

Table 4 shows that children with less zinc 
intake of $84.2 \%$ had low serum zinc levels. There was a significant relationship between $\mathrm{Zn}$ intake and serum Zn-levels in children ( $p=0.026$; PR 4.923).

Table 5: The relation between levels of zinc serum and level of intelligence

\begin{tabular}{|c|c|c|c|c|c|c|c|c|}
\hline \multirow[t]{3}{*}{ Zn serum level } & \multicolumn{4}{|c|}{ Intelligence level } & \multirow{2}{*}{\multicolumn{2}{|c|}{ Total }} & \multirow[t]{3}{*}{$\mathrm{p}$} & \multirow{3}{*}{$\begin{array}{l}\mathrm{PR} \\
95 \% \mathrm{Cl}\end{array}$} \\
\hline & \multicolumn{2}{|c|}{$\begin{array}{l}\text { Below } \\
\text { average }\end{array}$} & \multicolumn{2}{|c|}{$\begin{array}{l}\text { Average above } \\
\text { average }\end{array}$} & & & & \\
\hline & $\mathrm{n}$ & $\%$ & $n$ & $\%$ & $\mathrm{n}$ & $\%$ & & \\
\hline Low & 28 & 96.5 & 1 & 3.5 & 29 & 100 & 0.001 & 24.500 \\
\hline Normal & 8 & 53.3 & 7 & 46.7 & 15 & 100 & & $(2.614-229.624)$ \\
\hline Total & 36 & 81.8 & 8 & 18.2 & 44 & 100 & & \\
\hline
\end{tabular}

Table 5 shows that children who have low serum Zn-levels of $96.5 \%$ have intelligence levels below the average. There was a significant relationship between serum Zn-levels and children's intelligence $(p=0.001 ; 24.500)$.

\section{Discussion}

Based on the research results, it was found that $43.2 \%$ of children had insufficient zinc intake and $65.9 \%$ of children had low serum zinc levels (Table 2 ). Low zinc intake results in low serum zinc levels in children. Inadequate zinc intake is caused by a low intake of zinc-containing foods. The results of this study also indicated that there was a significant relationship between zinc intake and serum zinc levels (Table 4). Food intake is very dependent on the level of education and economic status of parents. In rural areas, low economic status or poverty occupies the first position in society which causes malnutrition. In this study, most of the parents had low education and had a low economic status (Table 1). Educational factors and low economic status will interact with each other in influencing nutritional intake in children [9].

Besides, limited employment opportunities in rural areas result in limited family ability to meet children's nutritional needs. This results in children consuming more plant-based foods and consuming less animal foods, while plant-based foods contain lots of phytates which inhibit the absorption of zinc [11]. Zinc is found in food, especially in animal protein sources [12]. Zn absorption is inhibited by interactions with iron, calcium, fiber, as well as phytates, which are found in grains, nuts, wheat, and whole grains [13]. Low concentrations of zinc in the body are an indicator of zinc deficiency.

Zinc deficiency in children can result in loss of appetite, taste disorders, growth disorders, alopecia, immune dysfunction, hypogonadism, difficult to heal wounds, and cognitive impairment [14]. Zinc concentrations are highest in the hippocampus (located in the temporal lobe) and cortex (outer layer) big brain [15] The cerebrum influences the level of intelligence and the ability to think [16]. Animal studies have shown that severe zinc deficiency is associated with damage to brain structures such as anencephaly, microcephaly, and hydrocephaly as well as impaired motor and behavioral responses [17].

Zinc can affect cellular function and critical processes of brain growth, including cell replication, synthesis of DNA and RNA, release of neurotransmitters, protein synthesis, and macronutrient metabolism [18], [19]. The results of this study indicated that there was a significant relationship between serum zinc levels and intelligence level (Table 5). About $96.5 \%$ of children who have low serum zinc level have intelligence level below average. The results of this study are in line with research conducted by Xuedong et al. on children aged 7-10 years, which stated that zinc levels in hair were positively related to IQ scores, namely, the higher zinc levels in hair, the higher the IQ score [20]. Jagveer et al. on children aged 6-11 years also stated that zinc deficiency is associated with memory and concentration deficits in children [21]. Research by Victoria et al. stated that high serum zinc levels have a beneficial impact on intellectual development [22]. Results of the Umamaheswari et al. study, stated that, giving zinc supplementation had an effect on short-term memory in children [23]. Likewise research conducted by Jagveer et al. showed that, there was a significant increase in children's memory and concentration in learning and children's brain intelligence or IQ after zinc supplementation was given [21].

According to Gogia and Sachdev, zinc is an essential nutrient that plays a role in the preparation, and migration of neurons (nerve cells) along with the formation of neuronal synapses. Zinc will release the neurotransmitter aminobutyric acid which will affect nerve stimulation. Aminobutyric acid neurotransmitters have a role in the growth and differentiation of nerve cells. Zinc deficiency can interfere with the formation of nerve pathways and neurotransmission, so that it indirectly affects development, including cognitive development [24].

\section{Conclusion}

Zinc deficiency in children is characterized by low serum $\mathrm{Zn}$-levels. Low serum $\mathrm{Zn}$-level is caused by low zinc intake, thus children with low serum Zn-levels are at risk of having intelligence level below average. Therefore, health education about the importance of zinc intake in children should be given to parents, so that the incidence of zinc deficiency in children can be reduced. 


\section{Acknowledgment}

This research was supported by a research funding grant of the Hibah Penelitian Dasar 2020 from The Indonesian Ministry of Research, Technology and Higher Education, contract number 0125.07/UN9/SB3.LP2M. PT/2020 with Dr. Rostika Flora as the Chief Researcher.

\section{References}

1. Dijkhuizen MA, Wieringa FT, West CE, Muherdiyantiningsih, Muhilal. Concurrent micronutrient deficiencies in lactating mothers and their infants in Indonesia. Am J Clin Nutr. 2001;73(4):786-91

\section{PMid: 11273854}

2. Herman S. Research Report on Micronutrient Problems in Indonesia, Exceptional Attention to Vitamin A Deficiency (VAD), Anemia, and Zinc. Jakarta: Ministry of Health of the Republic of Indonesia; 2007.

3. World Health Organization. Malnutrition: The Global Picture. Geneva: World Health Organization; 2004.

4. International Zinc Nutrition Consultative Group. International Zinc Nutrition Consultative Group (IZiNCG) technical document \#1. Assessment of the risk of zinc deficiency in populations and options for its control. Food Nutr Bull. 2004;25(1 Suppl 2):S99203. https://doi.org/10.1177/156482650402500220 PMid:18046856

5. Khan AA, Bano N, Salam A. Child malnutrition in South Asia: A comparative Perspective. South Asian Surv. 2007;14(1):129-45. https://doi.org/10.1177/097152310701400110

6. Almatrsier S. Prinsip Dasar IImu Gizi. Jakarta: PT, Gramedia Pustaka Utama; 2010.

7. Jagveer C, Rakesh J, Pramod S, Ravinder G, Sushil. A study of iron and zinc deficiency on short term memory in children $\&$ effect of their supplementation. Asian J Biomed Pharm Sci. 2015;5:12-5.

8. Setyaningrum R, Triyanti, Indrawani $\mathrm{Y}$. Learning in early childhood education with cognitive development in children. Natl Public Health J. 2014;8(6):243-24.

9. Wessells $\mathrm{KR}$, Brown $\mathrm{KH}$. Estimating the global prevalence of zinc deficiency: Results based on zinc availability in national food supplies and the prevalence of stunting. PLoS One. 2012;7(11):e50568. https://doi.org/10.1371/journal. pone. 0050568 PMid:23209782

10. Fesharakinia A, Zarban A, Gholam RS. Prevalence of zinc deficiency in elementary school children of South Khorasan
Province (East Iran). Iran J Pediatr. 2009;19(3):249-54.

11. Gropper SS, Smith JL, Groff JL. Advanced Nutrition and Human Metabolism. $5^{\text {th }}$ ed. Belmont, CA: Wadsworth Cengage Learning; 2009. p. 488-97.

12. Freake HC, Sankavaram K. Zinc: Physiology, dietary sources, and requirements. In: Encyclopedia of Human Nutrition. Vol. 4. UK: Elsevier; 2013. p. 437-43. https://doi.org/10.1016/ b978-0-12-375083-9.00286-5

13. Ma G, Li Y, Jin Y, Zhai F, Kok FJ, Yang X. Phytate intake and molar ratios of phytate to zinc, iron and calcium in the diets of people in China. Eur J Clin Nutr. 2007;61(3):368-74. https://doi. org/10.1038/sj.ejcn.1602513

PMid:16929240

14. Stipanuk MH, Caudill MA. Biochemical, Physiological, and Molecular Aspects of Human Nutrition. $3^{\text {rd }}$ ed. USA: Elsevier; 2013. p. 841-2.

15. Frederickson CJ, Koh JY, Bush AL. The neurobiology of zinc in health and disease. Nat Rev Neurosci. 2005;6(6):449-62.

PMid:15891778

16. Martini FH, Nath JL, Bartholomew EF. Fundamentals of Anatomy and Physiology. $9^{\text {th }}$ ed. Canada: Pearson; 2012. p. 449-50.

17. Nissensohn M, Sánchez-Villegas A, Fuentes Lugo D, Henríquez Sánchez P, Doreste Alonso J, Skinner AL, et al. Effect of zinc intake on mental and motor development in infants: A metaanalysis. Int J Vitam Nutr Res. 2014;83(4):203-15. https://doi. org/10.1111/mcn.12045

PMid:25008010

18. Levenson CW. Regulation of the NMDA receptor: Implications for neuropsychological development. Nutr Rev. 2006;64(9):428-32. PMid:17002239

19. Packer L, Sies H, Eggersdorfer M, Cadenas E. Micronutrients and Brain Health. USA: Taylor and Francis; 2010. p. 99. https:// doi.org/10.1201/9781420073522

20. Xuedong $Y$, Xiuzhen B. Relationship between contents of microelement zinc, cuprum, and lead in hair with children's intelligence quotient. J Math Med. 2006;4:430-2.

21. Chaudhary J, Jora R, Sharma P, Gehlot R, Sushil. A study of iron and zinc deficiency on short term memory in children \& effect of their supplementation. Asian J Biomed Pharm Sci. 2015;5(42):12-5. https://doi.org/10.15272/ajbps.v5i42.664

22. Victoria $P$, Eugenia $T$, lliana $P$. Zinc levels, cognitive and personality features in children with different socioeconomic backgrounds. Eur J Psychol. 2010;6(1):82-101.

23. Umamaheswari $\mathrm{K}$, Bhaskaran M, Krishnamurthy G Vasudevan $H$, Vasudevan $K$. Effect of Iron and Zinc Deficiency on Short Term Memory in Children. Indian Pediatr. 2011;48(4):289-93. https://doi.org/10.1007/s13312-011-0060-7 PMid:20972302

24. Gogia S, Sachdev HS. Zinc supplementation for mental and motor development in children. Cochrane Database Syst Rev. 2012;12:CD007991. https://doi.org/10.1002/14651858. cd007991 PMid:23235652 